Marek M. Dziekan*

\section{U źródeł polskich badań nad Kurdystanem}

DOI: http://dx.doi.org/10.12775/LC.2019.055

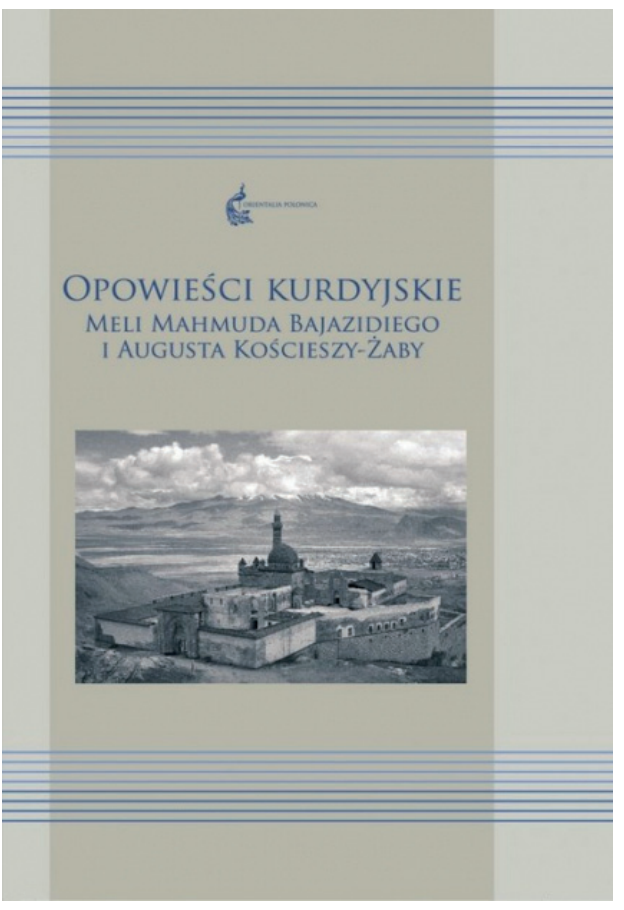

P

olskie badania naukowe w zakresie orientalistyki sięgają swoją historią pierwszej połowy XIX wieku i związane są przede wszystkim ze stosunkowo krótkim epizodem orientalistycznym na Uniwersytecie Wileńskim. W czasach tych, kiedy badania nad Orientem, rozumianym ówcześnie

* Prof. dr hab. nauk humanistycznych w zakresie literaturoznawstwa, kierownik Katedry Bliskiego Wschodu i Północnej Afryki na Wydziale Studiów Międzynarodowych i Politologicznych Uniwersytetu Łódzkiego.

E-mail: mmdziekan@interia.pl | ORCID: 00000003-0291-2997. przede wszystkim (choć nie wyłącznie) jako świat muzułmański, rozwijały się bujnie na zachodzie Europy a także w Rosji, sytuacja polityczna Polski nie pozwalała na szersze zajmowanie się tego typu działalnością, szczególnie w języku polskim. Mimo to już wcześniej powstawały pojedyncze prace o często dość znacznej wartości poznawczej. Pisane były nie tylko na podstawie opracowań, ale również $\mathrm{w}$ oparciu o oryginalne źródła w językach bliskowschodnich.

Dzieła te bez wątpienia warte są przypomnienia. Inicjatywę taką podjęła grupa orientalistów związanych z Uniwersytetem Jagiellońskim w ramach grantu Narodowego Programu Rozwoju Humanistyki, a efektem tych badań jest jedenaście tomów, które ukazały się w latach 2015-2018 nakładem krakowskiej Księgarni Akademickiej.

Seria ta ma znaczenie wielorakie. Z jednej strony przypomina Czytelnikom (w tym specjalistom!) zapomniane często dzieła, które powstały czy to w języku polskim, czy też $\mathrm{w}$ innych językach, których autorami byli orientaliści pochodzenia polskiego, co ukazuje „świadomość orientalistyczną” Polaków w minionych wiekach. Drugi aspekt to ukazanie ważnego fragmentu dziejów polskiej orientalistyki, zanim, od 1919 roku i powstania Seminarium Orientalistycznego pod kierownictwem prof. Tadeusza Kowalskiego na Uniwersytecie Jagiellońskim nastąpiła instytucjonalizacja tej nauki w Polsce.

Tom 9. serii „Orientalia Polonica”, który jest przedmiotem niniejszej recenzji ma, moim zdaniem, znaczenie szczególne. Wiąże się to zarówno z tematyką podjętą przez autora pracy, samą postacią autora, jak i faktem, że praca ta nie powstała $\mathrm{w}$ oryginale w języku polskim, dostęp do niej jest więc dodatkowo jeszcze utrudniony.

Zacznijmy może od autora. August (Aleksander) Kościesza-Żaba (w publikacjach francuskich Jaba) żył w latach 
1801-1894. Był dyplomatą i orientalistą, studiował na Uniwersytecie Wileńskim i w Instytucie Języków Wschodnich w Petersburgu. Należał do pokolenia Józefa Sękowskiego, Ludwika Spitznagla i Adama Mickiewicza, które fascynację Wschodem przejęło od profesorów Joachima Lelewela i Wilhelma Münnicha. Od 1828 roku Kościesza-Żaba pracował $\mathrm{w}$ rosyjskiej służbie dyplomatycznej na Bliskim Wschodzie, najpierw jako tłumacz, a później konsul w Erzurumie. Przebywając przez wiele lat w regionie, odbył szereg podróży i prowadził intensywne badania naukowe, specjalizując się w kurdologii. Był drugim polskim orientalistą, po Aleksandrze Chodźce, który zainteresował się tą kulturą, ale jednocześnie był pierwszym, który się w tej dziedzinie wyspecjalizował. W związku z tym prowadził badania terenowe na obszarze dzisiejszej Turcji i Iraku, gdzie znajdują się największe skupiska Kurdów. Ze względu na swą pracę dyplomatyczną był podejrzewany przez emigrację polską o denuncjowanie uciekinierów z terenów carskich do Turcji, co jednak nigdy nie zostało udowodnione, ale do pewnego stopnia zaważyło na recepcji jego postaci, choć oczywiście nie tak, jak w przypadku zrusyfikowanego na własne życzenie Józefa Sękowskiego.

Praktycznie cały dorobek naukowy Kościeszy-Żaby powstał w języku francuskim. W 1879 roku opublikował on jeden z pierwszych słowników języka kurdyjskiego, Dictionnaire kurde-français par M. Auguste Jaba, publié par M. Ferdinand Justi. Być może jednak najważniejszym jego dziełem, które znalazło zainteresowanie wspomnianego wyżej zespołu badawczego z UJ było opracowanie Recueil des notices et récits de la littérature et des tribus du Kourdistan (Petersburg 1860). Praca ta obejmuje 3 krótkie szkice dotyczące Kurdów: Informacje o niektórych plemionach kurdyjskich; Informacje o poetach $i$ autorach, którzy $w$ Kurdystanie pisali $w$ języku kurdyjskim... oraz Uwagi wstępne o nauce gramatyki języka kurman$d \dot{z} i \ldots$ i zbiór 40 opowieści kurdyjskich opublikowanych w języku oryginału, a także w przekładzie na język francuski. Praca poprzedzona jest wstępem niemieckiego orientalisty-kurdologa Petra Lerkha (także: Lerch).

Bardzo ważną w opracowaniu książki postacią jest Mela Mahmud Bajazidi, kurdyjski, dobrze wykształcony mułła z miejscowości Bajazyd, który był głównym informatorem naszego badacza.

Recenzowana książka stanowi przekład tekstu francuskiego pracy Kościeszy-Żaby uzupełniony Przedmowa do wydania polskiego Joanny Bocheńskiej oraz stosunkowo nielicznymi przypisami. W przekładzie dokonano do pewnego stopnia ujednolicenia pisowni nazw geograficznych, nazwisk i terminów orientalnych (nie tylko kurdyjskich, ale także perskich, tureckich i arabskich). We wstępie $\mathrm{w}$ tym kontekście jest mowa także o wprowadzeniu do polskiego przekładu zgodnej $\mathrm{z}$ oryginałem kurdyjskim nazwy „Stambul” (kurd. Istanbul) w miejsce „Konstantynopola” Kościeszy-Żaby. Autorka Przedmowy twierdzi, że w opowieściach muzułmanina, w których pojawia się to miasto, nazwa „Konstantynopol” „brzmi po prostu zabawnie i mało wiarygodnie" (s. XXV). Choć zgadzam się z Bocheńską, że należało w polskim przekładzie przywrócić nazwę „Stambul” z oryginału kurdyjskiego, to jednocześnie chciałbym podkreślić, że określenie „Konstantynopol” - w wersji arabskiej najczęściej „Kustantinijja” pojawia się w XIX-wiecznych tekstach pisanych przez bliskowschodnich muzułmanów równie często jak „Istanbul” i wcale nie brzmi to ani zabawnie ani mało wiarygodnie.

Wstęp Bocheńskiej umieszcza pracę Kośczieszy-Żaby i Bajazidiego, bo słusznie, jak się wydaje, główny informator badacza został uznany przez redaktorkę tomu za 
współautora dzieła, w kontekście epoki i ówczesnych badań kurdologicznych. Ważne jest zebranie przez Autorkę nielicznych, niestety, informacji o Bajazidim. Poza tym Joanna Bocheńska dokonuje bardzo pobieżnej próby oceny i interpretacji zamieszczonych w zbiorze opowieści. Ta część wstępu, jak sądzę, mogła być potraktowana szerzej, tak, jak na to zasługuje sam tekst $\mathrm{z}$ jednej strony, $\mathrm{z}$ drugiej zaś bolesny brak opracowań dotyczących Kurdów i Kurdystanu, szczególnie w kontekście kulturowym i literackim. O ile kwestie polityczne i społeczne znalazły zainteresowanie wśród polskich badaczy (np. Leszek Dzięgiel, Maria Giedz i oczywiście Joanna Bocheńska), a niedawno ukazała się także gramatyka języka kurdyjskiego autorstwa Andrzeja Pisowicza, to kwestie kultury do dziś pozostają na całkowitym marginesie zainteresowań polskich badaczy. Chlubnym wyjątkiem jest obszerne opracowanie pióra redaktorki tomu Między ciemnościa i światłem. O kurdyjskiej tożsamości i literaturze (2011). Ponieważ Bocheńska jest autorką tego właśnie opracowania, we wspomnianym wstępie oczekiwałem nieco głębszego spojrzenia w zebrane przez Kościeszę-Żabę opowieści. Szkoda, że Autorka nie podjęła się tego zadania.

Wartość recenzowanej pracy z punktu widzenia wiedzy o kulturze i literaturze kurdyjskiej trudno przecenić. Otrzymujemy bowiem niezwykle interesujące świadectwo ludowej świadomości Kurdów w XIX wie$\mathrm{ku}$, świadectwo, można tak powiedzieć, „z pierwszej ręki”. Opowieści dotyczą z jednej strony zarówno postaci historycznych, „przetrawionych” przez legendę i ludową wyobraźnię, z drugiej zaś opowieści na wskroś ludowe, można powiedzieć legendy, czy też - gdyby nie brak elementów magicznych - baśnie czy bajki. Dość pilnie obserwuję rynek polskich publikacji na tematy kurdyjskie i, o ile się nie mylę, są to pierwsze przekłady literatury kurdyjskiej na język polski, choć chętniej widziałbym tu przekłady oryginałów Bajazidiego, niż tłumaczeń Kościeszy-Żaby. Przekład z oryginału być może nie doprowadziłby np. do zagadkowego problemu, który w rzeczywistości nie jest problemem. W Opowieści dwunastej. Hasan Aga i Teleng Aga jedna z bohaterek ma na imię Lala Chan. W przypisie (s. 53) tłumaczka wskazuje, że nie wiadomo, o jakie imię chodzi - Lajla czy Lala, choć zapis kurdyjski jednoznacznie wskazuje na imię Lala (np. s. 31 tekstu kurdyjskiego).

Mojej opinii o wadze recenzowanej książki nie zmienia fakt, że czasem przekłady opowieści nie są doskonałe. Szczególnie widać to $\mathrm{w}$ pierwszych tekstach, gdzie zastosowane słownictwo czasem niezbyt licuje z XIX-wiecznymi realiami przekazów. W opowieści o chciwym mulle chwyta on „pojemniki na masło” (s. 25). Wydaje się, że można było znaleźć tu bardziej odpowiednie słowo, które nie powodowałoby „stylistycznego zgrzytu” w tekście. W opowieści czwartej (s. 29) pojawiają się „wyroby jedwabnicze”, a w opowieści jedenastej mamy „dochody generowane przez wioski” (s. 50) oraz „kreacje ozdobione diamentami” (s. 51). Należało się tu, moim zdaniem, nieco głębiej zastanowić nad odpowiednim doborem słów.

Nie dokonywałem kolacjonowania tekstu polskiego z francuskim, lecz zaniepokoiło mnie ostatnie zdanie w Opowieści szóstej. Deli Ismail Aga. Brzmi ono w przekładzie polskim: „[Kurdowie] Są w stanie poświęcić życie swoich dzieci, które jest im obojętne" (s. 37). Wywołało ono moje zaniepokojenie, sięgnąłem więc do tekstu Kościeszy-Żaby (pozycja ta jest w całości dostępna on-line), który brzmi: „La mort, la vie, le sort de leurs enfants sacrifiés, tot leur est indifférent" (s. 24). Chodzi więc o coś innego. Przekład Bocheńskiej sugeruje, że Kurdowie nie szanują swoich dzieci, w rzeczywistości zaś rzecz w tym, że w dążeniu 
do swojego celu Kurdowie są w stanie poświęcić absolutnie wszystko, nie zważając na śmierć, życie czy los własnych dzieci. I takiej właśnie pointy opowieści o Delim Ismailu Adze bym się spodziewat.

Mam nadzieję, że to tylko pojedynczy błąd, a inne opowieści nie zostały w ten sposób zniekształcone, przynajmniej nic nie wzbudziło mojego zaniepokojenia.

Opowieści kurdyjskie Augusta Kościeszy-Żaby i Meli Mahmuda Bajazidiego w dużym stopniu oddają wojowniczą naturę Kurdów (czego dowody otrzymujemy po dzień dzisiejszy w najnowszych doniesieniach z Bliskiego Wschodu o działaniach peszmergów) oraz niektóre elementy ich prawa zwyczajowego, najczęściej wymieszanego z szariatem, a także system wartości. Jest to jednak obraz wyrywkowy, taki, jaki może zaprezentować 40 opowiastek. Zgadzam się więc $\mathrm{z}$ opinią Joanny Bocheńskiej ze wstępu, że stwierdzenie Petra Lercka $\mathrm{z}$ jego przedmowy, że wyłania się z nich „dokładny i pełny obraz życia plemion kurdyjskich" (s. XXX) jest zdecydowanie przesadzony. Być może zresztą opinia ta osadzona jest w ówczesnych zachodnich przekonaniach i przesądach dotyczących „Orientu” (w rozumieniu Edwarda Saida).

Podsumowując, chciałbym podkreślić, że omawiana praca to ważny krok w zakresie polskich badań kurdologicznych (choć sięgający swymi początkami półtora wieku wstecz), a szczególnie ważny na drodze poznawania $\mathrm{w}$ Polsce dziedzictwa piśmiennictwa kurdyjskiego. Twórczość tę należy postrzegać nie w oderwaniu, lecz także w kontekście literatury sąsiednich etnosów - Arabów oraz rozmaitych ludów irańskich i turkijskich, z którymi dzieli ona zarówno sposób przekazu, jak i w wielu aspektach system wierzeń i wartości.

\section{Bibliografia}

Jaba, [Auguste] Alexandre 1860. Recueil de notices et récits kourdes servant à la connaissance de la langue, de la littérature et des tribus du Kourdistan. Réunis et traduits en français par M. Alexandre Jaba consul de Russie à Erzeroum. Saint-Pétersbourg: Commissionaire de l'Académie Impériale des Sciences.

Jaba, Auguste Ferdinand Justi 1879. Dictionnaire kurde-français. Saint-Pétersbourg: Commissionaire de l'Académie Impériale des Sciences.

Opowieści kurdyjskie Meli Mahmuda Bajazidiego i Augusta Kościeszy-Żaby 2018. Wstęp i opracowanie Joanna Bocheńska przy współpracy Marcina Rzepki. „Orientalia Polonica”. T. 9. Kraków: Księgarnia Akademicka. 